\title{
Antiviral Activity of Geopropolis Extract from Scaptotrigona Aff. Postica against Rubella Virus
}

\author{
Guilherme Rabelo Coelho ${ }^{1}$, Cristina Adelaide Figueiredo ${ }^{2}$, Giuseppina Negri ${ }^{3}$, Caroline C. Fernandes-Silva ${ }^{3}$, \\ Karina De Senna Villar ${ }^{1}$, Juliana Cuoco Badari ${ }^{2}$, Maria Isabel De Oliveira ${ }^{2}$, Tamyris Fernanda Barbosa ${ }^{2}$, Noemi \\ Nosomi Taniwaki ${ }^{4}$, Gislene Mitsue Namiyama ${ }^{4} \&$ Ronaldo Zucatelli Mendonça ${ }^{1}$ \\ ${ }^{1}$ Laboratório de Parasitologia, Instituto Butantan, Brazil \\ ${ }^{2}$ Núcleo de Doenças Respiratórias, Instituto Adolfo Lutz, Brazil \\ ${ }^{3}$ Laboratory of Phytochemistry, Department of Botany, Institute of Biosciences, University of São Paulo, Rua do \\ Matão 277 sala 154, CEP 05508-090, São Paulo SP, Brazil \\ ${ }^{4}$ Núcleo de Microscopia Eletrônica, Instituto Adolfo Lutz, Brazil \\ Correspondence: Giuseppina Negri, Laboratory of Phytochemistry, Department of Botany, Institute of \\ Biosciences, University of São Paulo, Rua do Matão 277 sala 154, CEP 05508-090, São Paulo SP, Brazil. E-mail: \\ gnegri@terra.com.br
}

Received: August 25, 2018

Accepted: September 12, $2018 \quad$ Online Published: October 13, 2018

doi:10.5539/jfr.v7n6p91

URL: https://doi.org/10.5539/jfr.v7n6p91

\begin{abstract}
The search for functional foods, which possess bioactive substances, is a new trend for the obtention of alternative and more effective treatments of many diseases with fewer side effects. Geopropolis, elaborated by stingless bees, is a mixture of plant resin sources, wax and soil. In the geopropolis from Scaptotrigona affinis postica (Latreille, 1807), (Hymenoptera, Apidae, Meliponini) was not observed the presence of soil. In a previous study, the extract of geopropolis provided by the beekeeper, from S. postica of Barra do Corda, Maranhão State, exhibited potent antiviral activity against herpes simplex virus. In this study, the propolis extract was prepared experimentally and characterized by RP-HPLC-DAD-ESI-MS/MS. The objective of this study was to evaluate the antiviral activity of an experimentally prepared geopropolis extract from $S$. postica against Rubella Virus infected Statens Serum Institute Rabbit Cornea (SIRC) cells. Rubella virus infection of susceptible women during the first trimester of pregnancy, often results in a combination of birth defects in newborns. There is not an effective treatment for rubella virus infection. Different protocols were carried out to evaluate, the antiviral effect of geopropolis extract on the viral replication of infectious RV. Cell viability and cell proliferation assays indicated that this geopropolis was not toxic to cultured SIRC cells. In the viral binding assay, antiviral assay, real-time PCR, and transmission electron microscopy, was observed that different concentrations of geopropolis $(17,34$ and $68 \mu \mathrm{g} / \mathrm{mL})$ was able to inhibit the binding of virions to the cell receptor and the production of infectious RV particles in post treated and pre treated infected SIRC cells. The antiviral activity could to be attributed to the high contents of the apigenin derivatives, vicenin-2 and schaftoside. As far as we know, this is the first report about the antiviral activity of geopropolis from Scaptotrigona postica against a Togaviridae virus.
\end{abstract}

Keywords: Rubella virus, antiviral activity, stingless bee, geopropolis, flavones-C-glycosides

\section{Introduction}

Rubella virus is classified as the only member of the genus Rubivirus belonging to the family Togaviridae. Rubella virus (RV) is a positive-sense, single-stranded RNA virus, hemagglutinin-containing surface projections. Chikungunya and Mayaro virus belong to the same family. Rubella, known more popularly as German measles, is a childhood disease, possessing a worldwide distribution (Parkman, 1996). Rubella virus is formed by the structural polypeptides, the membrane glycoproteins E1 and E2 and a single nonglycosylated RNA-associated capsid protein C (Lee \& Bowden, 2000). In a recent research, five genotypes of RV, 1E, 2B, 1J, 1I, and 1a were identified (Martínez-Torres et al., 2016). The vaccine is a live attenuated preparation of the virus (RA 27/3), which induces immunity by producing a modified rubella infection (Parkman, 1996). The vaccines produced by attenuated rubella virus are effective, however possess some side effects and are uneffective for pregnant women 
and immunodeficiency people (Petrova et al., 2016).

Postnatal rubella infection causes mild febrile illness accompanied by maculopapular rash and lymphadenopathy, while maternal infections during the first trimester of pregnancy result in a combination of birth defects in newborns, known as congenital rubella syndrome (Plotkin, 2011). RV can establish persistent infection in the developing fetus. Beside this, its replication can induce multiple pathological changes (Curti et al., 2013). It is estimated that more than 100,000 cases of congenital rubella syndrome occur in developing countries every year, representing a considerable social and economic burden ("WHO | World Health Organization," 2017). In a study carried out among 2012 and 2013, 68,968 rubella cases were registered in 28 countries of the WHO European Region (Muscat et al., 2014). The treatment for this virus infection is limited, since the commonly used antiviral drugs, acyclovir or immunoglobulin, are inefficient in the elimination of RV from chronically infected hosts (Gualberto et al., 2013).

Propolis is produced by Apis mellifera (Apidae) from resin of the leaf buds of numerous tree species, like birch, poplar, conifers, pine, alder, willow, palm, Baccharis dracunculifolia and Dalbergia ecastaphyllum (Huang et al., 2014; Li et al., 2016). Meliponinae is genera of Hymenoptera, known as stingless bees, which is highly social organisms that occur in tropical and subtropical areas throughout the world, including Brazil. Propolis produced by stingless bees, is a mixture containing plant resin source, wax and clay or soil particles (Massaro et al., 2014, Carneiro, et al., 2016). A study demonstrated that Corymbia torelliana is the resin source for the elaboration of geopropolis from Australian Tetragonula carbonaria, as was evidenced by the great similarity in their methylated flavanone profiles by HPLC analyses of their respective extracts (Massaro et al., 2014). Geopropolis from stingless bee Scaptotrigona affinis postica (Latreille, 1807), (Hymenoptera, Apidae, Meliponini), analysed in this study, contains no soil. Propolis and geopropolis possess the same chemical class of compounds, which are extracted from its respective resin source. Flavonoids, terpenes, phenylpropanoids, triterpenoids, catechins and caffeoylquinic acid derivatives were detected in geopropolis (Silva et al., 2014; Dutra et al., 2014; Batista et al., 2016; Sawaya et al. 2009; Ferreira et al., 2017). A pyrrolizidine alkaloid derived from retronecine was detected in geopropolis from stingless bee $S$. postica (Coelho et al., 2015). However, the chemical composition of propolis from Apis mellifera is qualitatively the same in the geographic region where it was produced. As for example, the resin source for European propolis is poplar species, for Brazilian green propolis is Baccharis dracunculifolia and for red South American propolis is Dalbergia ecastophyllum (Osés et al., 2015; Huang et al., 2014; Valenzuela-Barra et al., 2015).

On the other hand, in general, geopropolis show a wide variation even among samples from the same region, since stingless bee collect material from plants near their hives. Different chemical profile was observed among geopropolis samples from Melipona fasciculata Smith harvested in municipalities of Maranhão State, northeastern Brazil. Cycloartane, ursane and oleanane derivatives and phenolic acids (protocatechuic acid and gallic acid) were detected in geopropolis harvested in Palmeirândia, while gallic and ellagic acid were the main constituents detected in geopropolis harvested in Fernando Falcão (Batista et al., 2016). Phenolic acids and hydrolyzable tannins (gallotannins and ellagitannins) were detected in geopropolis from Melipona fasciculata harvested in Baixada Maranhense, also in Maranhão State (Dutra et al., 2014). However, samples of geopropolis from stingless bee Tetragonisca angustula, independently of their geographic origin, presented a similar composition to the flowers extracts of Schinus terebinthifolius Raddi (Anacardiaceae), their possible resins source (Carneiro et al, 2016).

There are more studies for Melipona than Scaptotrigona stinglees bee species (Santos et al., 2017). Sawaya et al. (2009) analysed geopropolis extract from three species of Scaptotrigona harvested monthly from two distinct regions in Brazil. Geopropolis from Scaptotrigona ssp. was harvested in the state of Maranhão, Northeastern region of Brazil, while geopropolis from Scaptotrigona aff. depillis and Scaptotrigona bipunctata was harvested in the state of São Paulo, South eastern region of Brazil. Diterpenes acid derivatives were found as the main constituents. However, was observed that, the chemical profile obtained for geopropolis from Scaptotrigona ssp., harvested in Maranhão State, was different for that obtained for the Scaptotrigona species harvested in São Paulo State (Sawaya et al. 2009). Flavonols, such as quercetin methyl ethers, and methoxy chalcones were detected in geopropolis from Scaptotrigona aff. depillis, harvested in the state of Rio Grande do Norte, Northeast region of Brazil (Ferreira et al., 2017).

In this study was carried out the chemical analysis and antiviral activity of an experimentally prepared extract of geopropolis (HMEG) from Scaptotrigona affinis postica harvested in Barra do Corda, Maranhão State, Brazil. HMEG were characterized by RP-HPLC-DAD-ESI-MS/MS. In the previous study was reported the chemical composition of an extract from S. postica of Barra do Corda, provided by the beekeeper, which exhibited the flavones-6,8-di-C-glycosides (vicenin-2 and schaftoside), a pyrrolizidine alkaloid derived from retronecine, 
catechin-3-O-gallate, 3,5-dicaffeoyl quinic acid and caffeoylquinic acid-O-arabinoside as the main constituents (Coelho et al., 2015). The ecosystems from Barra do Corda, Maranhão State, included mangrove swamps, floodplains, lakes, babassu palm and forests. In geopropolis from $S$. postica were identified 94 pollen types, which belonging to 35 plants families. Borreria verticillata $(34.17 \%)$ was the most frequent pollen type, followed by Anadenanthera sp. (13.65\%) and Mimosa caesalpiniifolia (10.5\%) (Souza et al., 2015).

The search for functional foods, that possess bioactive substances, is a new trend, which can provide more effective treatments of diseases with fewer side effects. The numerous bioactive compounds collected by honeybees from exudates and buds of plants, are utilized in the elaboration of propolis that exert a defensive barrier against microorganism (Saeed et al., 2016; Salas et al., 2016). It is extensively used for centuries, in foodstuffs and beverages to improve health related disorders. Propolis and geopropolis exhibited a wide variety of pharmacological properties, such as, anti-inflammatory, antioxidant, antitumor, antiulcer and for treatment of respiratory diseases (Berretta et al., 2017; Montenegro \& Mejías, 2013; Pippi et al., 2015; Nina et al., 2015). The antiviral activity of propolis from different geographic regions is known, since ancient times. Propolis has been pointed out as an alternative for the treatment of disease caused by virus, since its antiviral properties has been evidenced in different steps of viral replication (Silva-Carvalho et al., 2015; Saeed et al., 2016; Salas et al., 2016). Propolis exerted antiviral activity against influenza virus A and B, herpes, Vaccinia Virus, Hepatitis B Virus, Calicivirus, Newcastle disease virus, Avian reo virus, Bursal disease virus and human immunodeficiency virus (HIV) (Silva-Carvalho et al., 2015; Oldoni et al., 2015). The green propolis and its resin source Baccharis drancunculifolia exhibited antiviral activity on poliovirus type 2 (Búfalo et al., 2009). Propolis extracts exhibited high anti-herpetic activity against Herpes virus type I and II, by different mechanism of action (Nolkemper et al., 2010; Schnitzler et al., 2010), and anti-influenza virus activity against influenza infection in mice (Shimizu et al., 2008). The hydroalcoholic extract from Brazilian brown propolis promoted protective effect on herpes infected mice, acting on inflammatory and oxidative processes (Sartori et al. 2012). Hatay propolis samples exhibited antiviral effects against Herpes virus type I and II (Yildirim et al., 2016). Propolis extract collected in a Canadian region, rich in poplar trees, exhibited high virucidal effect against herpes simplex viruses type 1 and type 2, due to its interference in virus adsorption (Bankova et al., 2014). The geopropolis from S. postica, that contain high contents of vicenin-2 and schaftoside, exhibited high antiviral activity against herpes virus (Coelho et al. 2015). The results obtained in different studies had shown that propolis with different chemical profile, harvested in different geographic region exhibited antiviral activity against herpes simplex viruses and other types of virus (Coelho et al. 2015, Bankova et al., 2014, Yildirim et al., 2016). Attachment to cellular receptors and entry into the host cell are the first steps in viral infection (Rasbach et al., 2013). It is known that flavonoids can prevent the virus binding to host cell receptor and penetration within cells, exerting an inhibitory effect on the early stage of virus infection (Ahmad et al., 2015; Kai et al., 2014).

The aim of this study was to evidence the effectiveness of an experimentally prepared extract of geopropolis (HMEG) from S. postica, harvested in Barra do Corda, Maranhão State, against Rubella virus infected Statens Serum Institut Rabbit Cornea (SIRC) cells. In the present study, viral binding and penetration assays were included, to determine if treatment of RV with an extract rich in flavones-6,8-di- $C$-glycosides could disrupt virions from binding to the SIRC receptor of the cell membrane and its penetration into the cell.

\section{Material and Methods}

\subsection{Cells}

The SIRC cells (rabbit cornea - ATCC CCL-60) were grown in $75 \mathrm{~cm}^{2}$ plastic cell culture flasks, in DMEM medium (Dulbecco's minimum Eagle essential medium) supplemented with 10\% inactive fetal bovine serum (FBS) and $20 \mathrm{mM} \mathrm{L-glutamine} \mathrm{(Invitrogen,} \mathrm{EUA).}$

\subsection{Preparation and Phytochemical Analysis of Experimentally Prepared Extract of Geopropolis (HMEG) from S. Postica using Reversed Phase HPLC-DAD-ESI-MS/MS.}

Geopropolis sample (15 g) from S. postica harvested in the region of Barra do Corda, Maranhão state, Brazil, ( $5^{\circ}$ $30^{\prime} \mathrm{S}, 45^{\circ} 14^{\prime} \mathrm{O}$ ) was treated with solvents of increasing polarity (hexane, chloroform, ethyl acetate and methanol) in Sohxlet apparatus. The obtained fractions were concentrated and stored at freezer until sample workup. The yield of methanolic extract was $15.08 \%$ by dry weight. For antiviral tests, the dry methanolic fraction, was dissolved in water and denominated HMEG. This extract rich in hydrosoluble compounds was analyzed by HPLC-DAD-ESI-MS/MS. The analysis was conducted on DADSPD-M10AVP Shimadzu system equipped with a photodiode array detector coupled to Amazon speed ETD, Bruker Daltonics, as previously described by Coelho et al. (2015). The identification of constituents was established on the basis of their UV and mass spectral (MS) data, which were compared with MS data reported by Coelho et al. (2015), Negri et al. (2018), Mihajlovic et al. 
(2015) and the chemical databases Phenol-Explorer (www.phenol-explorer.eu), Chem. Spider (http://www.chemspider.com), METLIN (http://metlin.scripps.edu) and HMDB (www.hmdb.ca).

\subsection{Cell Viability - MTT Assay}

Cell viability were determined using MTT (3-[4,5-dimethylthiazol 2-yl]-2,5 diphenyl tetrazolium bromide). The MTT assay was carried out using the methodology reported by Coelho et al., (2015) with modifications. SIRC cells were seeded at concentration of $10^{4}$ cells/well in 96-well plates, which was grown at $37{ }^{\circ} \mathrm{C}$ for 1 day. After $48 \mathrm{hs}$, cells were treated with different concentrations of HMEG $(0,0.3,0.6,1.2,2.4,8.6,17.2,34,68$, and 150 $\mathrm{ug} / \mathrm{mL}$ ) and phosphate buffered saline (PBS) (control negative).

\subsection{Determination of the Virus Infectious Dose}

The determination of the virus infectious dose was carried out using the methodology reported by Coelho et al. (2015) with modifications. The confluent monolayers were dispersed with $0.2 \%$ trypsin and $0.02 \%$ versene, resuspended in Dulbecco's minimum Eagle essential growth medium (DMEM) with $100 \mathrm{IU} / \mathrm{ml}$ penicillin G and $100 \mathrm{mg} / \mathrm{ml}$ streptomycin. The SIRC cell suspension was diluted to $2.0 \times 10^{4}$ cells $/ \mathrm{ml}$ and placed into $96-$ well plate. Plates were seeded with $200 \mu \mathrm{L}$ of cell suspension and incubated at $37^{\circ} \mathrm{C}$ in a humidified $5 \% \mathrm{CO}_{2}$ atmosphere. RA 27/3 strain (Meruvax II, Merck, Sharp and Dohme) stock virus was quantified by medium tissue, using cell culture infections with $0.01 \mathrm{MOI}$ (multiplicity of infection). HMEG was added to the cells at $3 \mathrm{~h}$ prior of the virus infections (pre treatment) and $1 \mathrm{~h}$ after virus infection (post treatment). The antiviral screenings were repeated three times with different concentrations of $\operatorname{HMEG}(0.6,2.4,8.6,17,34$ and $68 \mu \mathrm{g} / \mathrm{mL})$.

\subsection{Antiviral Effect of Geopropolis on Infected SIRC Cells}

The antiviral effect was evaluated according to the method described by Carvalho et al. (2017) and Coelho et al. (2015) with modifications. SIRC cells were grown to approximately 90\% confluence in 96 well plates in DMEM, supplemented with $2 \mathrm{mM}$ of L-glutamine and $10 \%$ phosphate buffered saline (PBS). Plates were incubated at $37^{\circ} \mathrm{C}$ in a humidified 5\% $\mathrm{CO}_{2}$ atmosphere. The confluent cells were infected with RA 27/3 (MOI=0.1) and monitored for cytopathic effects, for 3 days. The extract was added to the cells at $3 \mathrm{~h}$ prior of the virus infections (pre treatment) and $1 \mathrm{~h}$ after virus infection (post treatment). The antiviral screenings were independently repeated, three times with different concentrations of $\operatorname{HMEG}(0.6,2.4,8.6,17,34$ and $68 \mu \mathrm{g} / \mathrm{mL})$. After this, the determination of the HMEG effect on the infected cells was carried out using Real-Time quantitative polymerase chain reaction (qPCR).

\subsection{Binding-penetration Assays}

The aim of binding-penetration assays is to measure interactions between virus and cells. These assays were carried out according to the method described by Carvalho et al. (2017) with modifications. The binding assay was carried out at $4^{\circ} \mathrm{C}$, a temperature that allowed the binding of RV to cell receptors. In this temperature RV cannot penetrate within cells. The penetration occurs most efficiently at $37^{\circ} \mathrm{C}$. SIRC cells were placed in 24 -well plate and allowed to reach confluency. The cells were infected with RV (MOI=0.1) dilutions and treated with different concentrations of HMEG $(17,34$ and $68 \mu \mathrm{g} / \mathrm{mL})$. The infected SIRC cells treated or untreated were allowed to adsorb for $1 \mathrm{~h}$ at $4{ }^{\circ} \mathrm{C}$. Unabsorbed virions were then aspirated, and the cells were washed twice with PBS and were again treated with different concentrations of HMEG $(17,34$ and $68 \mu \mathrm{g} / \mathrm{mL})$ for $1 \mathrm{~h}$ at $37^{\circ} \mathrm{C}$ and $5 \%$ $\mathrm{CO}_{2}$. RV virions penetrated within cells at $37^{\circ} \mathrm{C}$ to complete its life cycle. Unabsorbed virions were then aspirated, and the cells washed with PBS twice. After this, cells were incubated for $72 \mathrm{~h}$ at $37^{\circ} \mathrm{C}$ and $5 \% \mathrm{CO}_{2}$. The results were analysed using qPCR.

\subsection{Quantitative Real-time PCR Assay - qPCR}

Quantitative real-time PCR (qPCR) is used for the quantification of viral nucleic acids, being a reliable method for measure gene expression (Carvalho et al. 2017). The total RNA for evaluation of antiviral activity of HMEG in pre treatment, post treatment, binding and penetration assay was measured by qPCR. The quantification was carried out according to the method described by Coelho et al., (2015) and Carvalho et al. (2017) with slight modification. The extraction of total RNA from homogeneous cell group, were carried out using the MagNA Pure extractor (Roche, Basel, Switzerland). To amplify the RV genomic sequence, Real-Time quantitative polimerase chain reaction (RT-PCR) was performed using the Superscript III Step RT-PCR kit (Invitrogen, Carlsbad, CA, USA), according to the manufacturer's recommendations. The set of primers used was described by CDC/USA (Abernathy et al. 2009). The assay was performed in triplicate with $25 \mu 1$ reactions mixtures containing reaction buffer (Invitrogen, Carlsbad, CA, USA), $0.5 \mathrm{U}$ of a Superscript-Taq enzyme mixture, $0.2 \mu \mathrm{M}$ of each primer, $0.1 \mu \mathrm{M}$ of the labeled probe (Invitrogen, Carlsbad, CA, USA) and $5 \mu 1$ of RNA. The assay was carried out also including a no-template control. The thermal cycling was carried out with an Applied 
Biosystems 7500 thermal cycle with the following procedure: $50 \mathrm{C}$ for $10 \mathrm{~min}$; $95 \mathrm{C}$ for $2 \mathrm{~min}$; and 40 cycles of $95 \mathrm{C}$ for $15 \mathrm{~s}$ and $60 \mathrm{C}$ for $1 \mathrm{~min}$. The presence of intact RNA in the samples was confirmed with primers specific for RNase P RNA. Standard curves were prepared by qPCR using serial dilutions of known copy numbers of the purified amplification product for RV. A reaction mixture containing water as the template was run on each plate as negative control. The percentage of reduction was defined as follows: [copy no. of infected cells - copy no. of treated cells/copy no. of infected cells X 100]. The data were analysed with SDS software (version 2.1; Applied Biosystems, Grand Island, NY, USA).

\subsection{Transmission Electron Microscopy (TEM)}

The transmission electron microscopy was carried out according to the methodology reported by Coelho et al., (2015) and Carvalho et al. (2017) with slight modification. SIRC cells were cultivated on Aclar film seeded in 24-well plates and incubated for $48 \mathrm{~h}$ at $37{ }^{\circ} \mathrm{C}$ in a humidified atmosphere with $5 \% \mathrm{CO}_{2}$. $\mathrm{RVs}(\mathrm{MOI}=0.1)$ were treated with $68 \mu \mathrm{g} / \mathrm{mL}$ of HMEG for $1 \mathrm{~h}$ at $37^{\circ} \mathrm{C}$ prior to cell infection. DMSO used as the negative control, did not exhibited any noticeable effects on the cell lines. The cells inoculated with RV, treated and untreated with HMEG, and allowed to adsorb RV for $1 \mathrm{~h}$ at $37{ }^{\circ} \mathrm{C}$ in $5 \% \mathrm{CO}_{2}$. After $48 \mathrm{~h}$, the cells were fixed with $2.5 \%$ glutaraldehyde (Sigma, St. Louis, MO, USA) in $0.1 \mathrm{M}$ sodium cacodylate buffer (pH 7.2) for 2 hours at $4^{\circ} \mathrm{C}$. After rinsing with cacodylate buffer, the cultures were post-fixed in a solution containing $1 \%$ osmium tetroxide, washed in $0.1 \mathrm{M}$ sodium-cacodylate buffer, dehydrated in graded acetone, and embedded in epoxy resin. Ultrathin sections stained with uranyl acetate and lead citrate were examined under a Jeol Transmission Electron Microscope at $80 \mathrm{kV}$. Images were recorded under a JEM-1011 transmission electron microscope (JEOL, Tokyo, Japan).

\subsection{Statistical Analysis}

Statistical analysis was performed using Exstat software. For analyses of the cell viability data and the antiviral activity by mRNA quantification, the Student's T test was used with the $p$ value corrected by the BonferroniSidak method.

\section{Results}

\subsection{Antiviral Effect of HMEG on SIRC Infected Cells}

Results of cell viability and cell proliferation assays indicated that HMEG was not toxic to cultured SIRC cells. SIRC infected cells were treated with different concentrations of HMEG $(0.6,2.4,8.6,17,34$ and $68 \mu \mathrm{g} / \mathrm{mL})$ prior to RV infection (pre treated cells) and after infection (post treated cells). In the MTT assay was not observed cytotoxic effect on SIRC cells treated with HMEG at concentration of $68 \mathrm{ug} / \mathrm{mL}$, as can be seen in Figure 1. The 50\% cytotoxic concentration (CC50) of HMEG was $150 \mathrm{ug} / \mathrm{mL}$. As can be seen in Figure 2, the post treatment and pre treatment with HMEG reduced the number of copies of RV in the cell lysates, reducing the viral load, which was dose dependent. In the pre treatment with HMEG, the reduction of viral load ranged from $20 \%$ to $90 \%$. On the other hand, was observed a reduction of $80 \%$ of viral load, after post treatment with $0.6 \mu \mathrm{g}$ of HMEG. The post treatment carried out with $68 \mu \mathrm{g} / \mathrm{mL}$ of HMEG resulted in $98 \%$ of inhibition of the viral replication (see Figure 2).

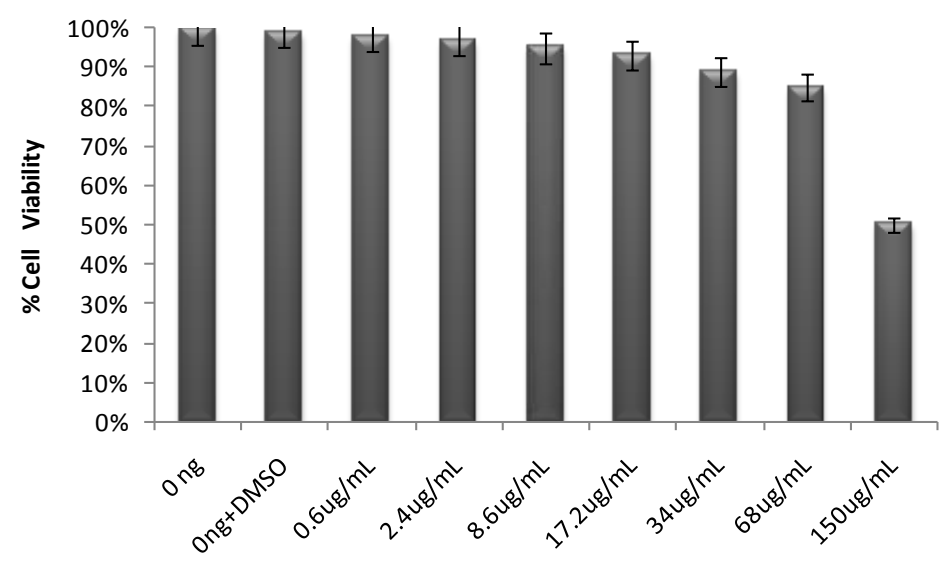

Figure 1. Cell viability of SIRC cells treated with different concentrations of HMEG. The number represents the mean of three replicates 


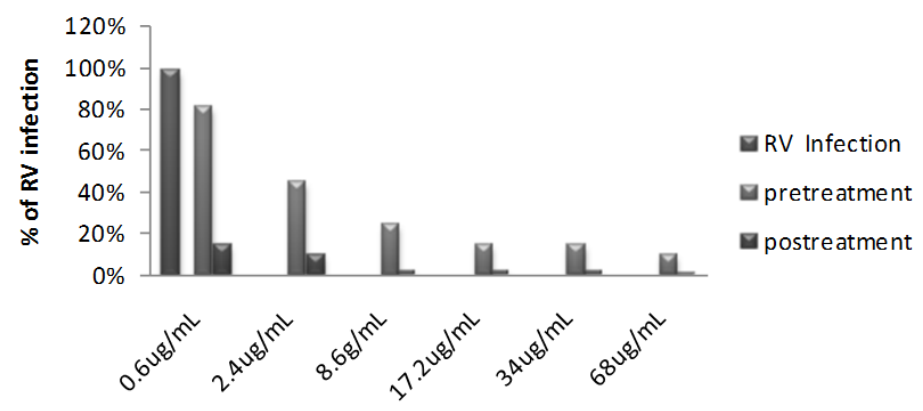

Figure 2. RV treated with geopropolis (pre treatment and post treatment). The infectivity of RV decreased after pre treatment and post treatment, with HMEG. Infectivity was determined by qPCR. The errors bars represent the SD from three replicates for each set of values. It is important to observe that the inhibitory infection was more than $90 \%$ with concentrations of HMEG $2.4 \mathrm{ug} / \mathrm{mL}$.

The viral binding assay was performed at $4^{\circ} \mathrm{C}$, to determine if treatment of RV with HMEG could disrupt virions from binding to the SIRC cellular receptor. In this temperature did not occur the penetration of RV within SIRC cells, which occur after the increase of temperature at $37^{\circ} \mathrm{C}$, completing its life cycle. The cytopathic effect was observed in the cells infected and untreated and in cells DMSO-treated RVs, however was not observed with RV infected SIRC cells treated with HMEG. In the viral binding assay was observed that the treatment of infected SIRC cells with different concentrations of HMEG $(17,34$ and $68 \mu \mathrm{g} / \mathrm{mL})$, was efficient to block the binding the virus on cell receptor, inhibiting the infection of SIRC cells, as can be seen in Figure 3. Thus, the results (repeated in triplicates) indicate that HMEG was able to inhibit the binding of virions to the SIRC cells receptor. Virus binding to cellular receptors leads to the direct penetration into cells. Beside this, the results obtained by penetration assays (Figure 4), indicated that HMEG efficiently prevented viral penetration and replication.

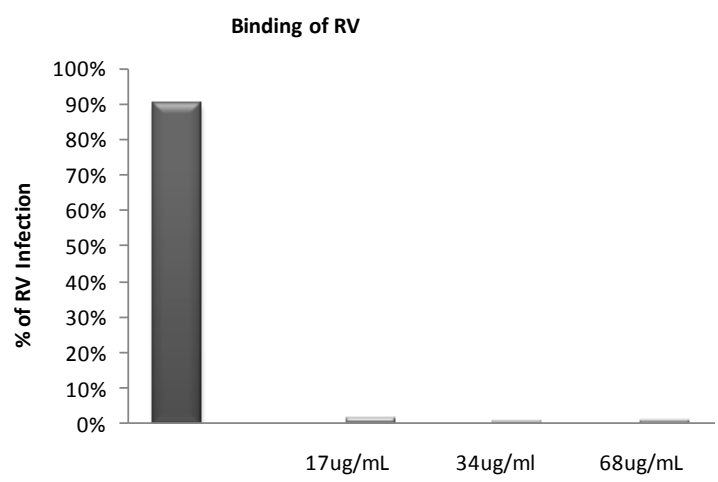

Figure 3. Binding assay of untreated virus and RV treated with HMEG (17, 34 and 68ug/mL) on receptor of SIRC cells. Infectivity was determined by qPCR. The numbers represent the mean triplicate trials

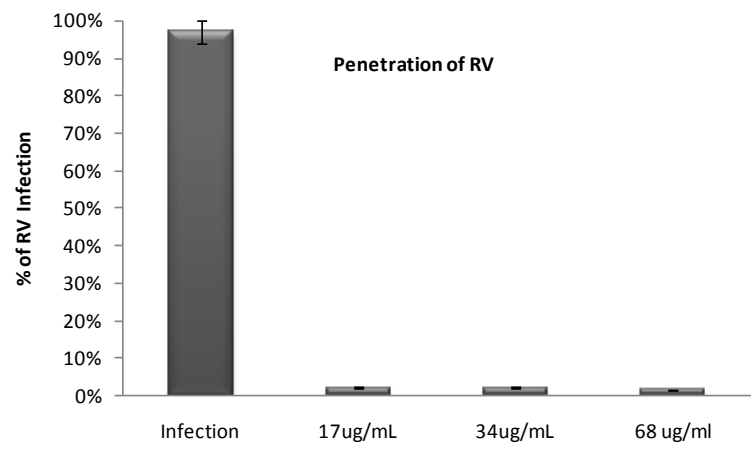

Figure 4. Penetration assay of untreated or RV treated with HMEG (17, 34 and 68ug/mL) within SIRC cells. Infectivity was determined by qPCR. The numbers represent the mean of triplicate trials 
The reduction of viral load was observed by qPCR, which indicated a decrease of the RNA copy number of RV. These results were corroborated by TEM assay. As can be seen in Figure 5, in the electron micrographs, in the cytoplasm of infected SIRC cells treated with HMEG, were not observed the rearrangement of organelles and the presence of RV-like particles.

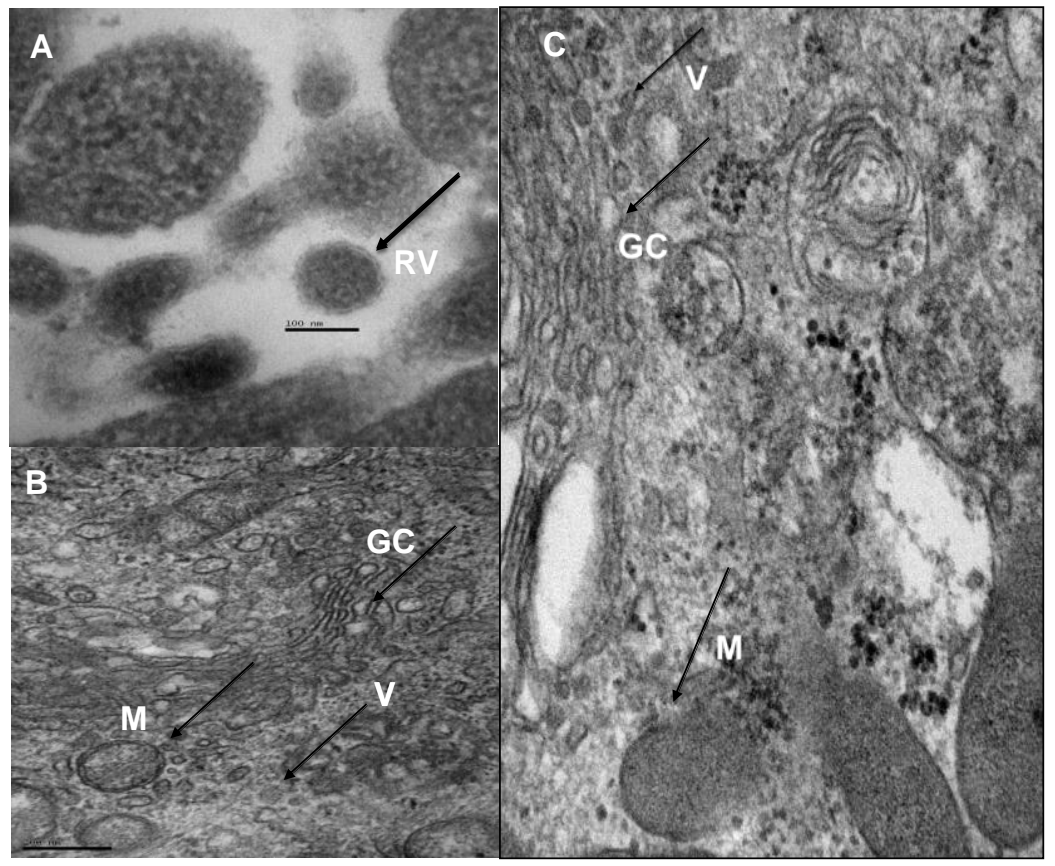

Figure 5. The SIRC cells were cultivated on Aclar film and after 48 hours were inoculated with binding sample and processed by TEM. A- SIRC cells inoculated with RV. Note the presence of a typical particle viral. B- SIRC cells inoculated with binding sample. Note Golgi complex (GC), Vesicles (V) and Mitochondria (M). C- SIRC cells inoculated with virucida sample. It is important to note that RV like particles is not found. The Golgi complex (GC), Vesicles (V) and Mitochondria (M) are marked in the cells.

\subsection{Phytochemical Analysis of Experimentally Prepared Extract of Geopropolis (HMEG) using Reversed Phase HPLC-DAD-ESI-MS/MS}

The chemical profile of experimentally prepared extract of geopropolis (HMEG) from $S$. postica was similar that obtained for extract provided by beekeeper (Coelho et al., 2015). The only difference observed was the presence of low contents of hydroxycinnamic acid amide derivatives in HMEG. The presence of hydroxycinnamic acid amide derivatives were reported in Apis mellifera pollen (Negri et al. 2011, 2018). Table 1 summarises the MS data of compounds $\mathbf{1} \mathbf{- 2 2}$ detected in HMEG, through reversed phase HPLC-DAD-ESI-MS/MS. The method used for the identification of vicenin-2 (7); schaftoside (10); 5-O-caffeoylquinic acid arabinoside (23) and the pyrrolizidine alkaloid 7-(3-methoxy-2-methylbutyryl)-9-echimidinyl retronecine (2) was reported by Coelho et al., (2015). The flavones-6,8-di-C-glycosides, vicenin-2 (7) and schaftoside (10) was found as the main constituents in both extracts. Catechin-C-arabinoside (8) and catechin-C-rhamnoside (9) were identified based on mass spectral data reported in literature (Karar \& Kuhnert, 2015). The identification of hydroxycinnamic acid amide derivatives were performed according to the method reported by Negri et al. $(2011,2018)$ and Mihajlovic et al. (2015). As can be seen in Table 1, the MS/MS experiments in protonated hydroxycinnamic acid amide (HAA) derivatives produced abundant fragment ions attributed to the acyl neutral losses, as for example $176 \mathrm{Da}$ for feruloyl, $162 \mathrm{Da}$ for caffeoyl, and $146 \mathrm{Da}$ for coumaroyl moieties, which was followed by neutral water loss (18 Da) (Negri et al., 2011). While the MS/MS experiments in deprotonated hydroxycinnamic acid amide derivatives produced abundant fragment ions, attributed to the loss of 120 Da for HAA containing coumaric acid moiety; the loss of $136 \mathrm{Da}$ for HAA containing caffeic acid moiety; and the loss of $150 \mathrm{Da}$ for HAA containing ferulic acid moiety (Mihajlovic et al., 2015, Negri et al., 2018).

Compound 20 was tentatively identified as 6-C-fucosyl luteolin, since in its MS/MS spectrum was observed the loss of water (Table 1), which is representative of C-6-isomers (Elliger et al., 1980). The presence of 
pyrrolizidine alkaloids was reported in bee products. When bees collect resins of plants that contain pyrrolyzidine alkaloids, these compounds can be transferred into geopropolis, propolis or honey (Dübecke, Beckh, \& Lüllmann, 2011). Pyrrolizidine alkaloids possess 1-hydroxymethyl pyrrolizidine necine base. They rarely occur in the free form, generally occurring as esters (mono-, di- or macrocyclic diesters) (Moreira et al., 2018). The pyrrolizidine alkaloids 7-(3-methoxy-2-methylbutyryl)-9-echimidinyl retronecine (2) and 7-(3-dihydroxy-propoxy-2-methylbutyryl)-9-echimidinyl retronecine (6) (Table 1) occur as necine base (retronecine) and contain esters groups at C-9 and C-7.

Table 1. Compounds 1-22 detected in experimentally prepared extract of geopropolis from $S$. postica (HMEG) of Barra do Corda, Maranhão State, by HPLC-DAD-ESI-MS/MS analyses

\begin{tabular}{|c|c|c|c|c|c|}
\hline $\mathrm{N}^{\mathrm{O}}$ & $\begin{array}{l}\mathrm{Tr} \\
\min \end{array}$ & $\begin{array}{l}\text { HPLC/DAD } \\
\operatorname{Max}(\mathrm{nm})\end{array}$ & $\begin{array}{l}\mathrm{HPLC} /(+) \mathrm{ESI}-\mathrm{MS} / \mathrm{MS} \\
\mathrm{m} / \mathrm{z}(\% \text { base peak })\end{array}$ & $\begin{array}{l}\mathrm{HPLC} /(-) \mathrm{ESI}-\mathrm{MS} / \mathrm{MS} \\
\mathrm{m} / \mathrm{z}(\% \text { base peak })\end{array}$ & Identification \\
\hline 1 & 2.8 & 320 & & $\begin{array}{l}{[\mathrm{M}-\mathrm{H}]^{-}-341} \\
\mathrm{MS} / \mathrm{MS}-179\end{array}$ & 6-O-caffeoyl glucoside ${ }^{\mathrm{a}}$ \\
\hline 2 & 3.5 & - & $\begin{array}{l}{[\mathrm{M}+\mathrm{H}]^{+}-430} \\
\mathrm{MS} / \mathrm{MS}-412(100), \\
385(70), 315(20)\end{array}$ & $\begin{array}{l}{[\mathrm{M}-\mathrm{H}]^{-}-428} \\
\mathrm{MS} / \mathrm{MS}-398\end{array}$ & $\begin{array}{l}\text { 7-(3-methoxy-2-methylbutyr } \\
\text { yl)-9- echimidinyl } \\
\text { retronecine }\end{array}$ \\
\hline 3 & 4.1 & - & $\begin{array}{l}{[\mathrm{M}+\mathrm{H}]^{+}-541} \\
\mathrm{MS} / \mathrm{MS}-523(100), \\
472(20), 444(40)\end{array}$ & & $\begin{array}{l}\text { methoxy- } \\
\text { heptahydroxy-flavone-3-O-g } \\
\text { lucuronide }{ }^{c}\end{array}$ \\
\hline 4 & 5.5 & $260-355$ & $\begin{array}{l}{[\mathrm{M}+\mathrm{H}]^{+}-555} \\
\mathrm{MS} / \mathrm{MS}-537 \quad(100), \\
486(20), 454(30)\end{array}$ & & $\begin{array}{l}\text { dimethoxy- hexahydroxy- } \\
\text { flavone-3-O-glucuronide }\end{array}$ \\
\hline 5 & 6.0 & $260-355$ & $\begin{array}{l}{[\mathrm{M}+\mathrm{H}]^{+}-641} \\
\mathrm{MS} / \mathrm{MS}-479(90), 317 \\
(100)\end{array}$ & & $\begin{array}{l}\text { Isorhamnetin-7,3-O- } \\
\text { diglucoside }^{\mathrm{c}}\end{array}$ \\
\hline 6 & 6.5 & - & $\begin{array}{l}{[\mathrm{M}+\mathrm{H}]^{+}-490} \\
\mathrm{MS} / \mathrm{MS}-473(40), 445 \\
(100), 315(60)\end{array}$ & & $\begin{array}{l}\text { 7-(3-dihydroxy-propoxy-2- } \\
\text { methylbutyryl)-9- } \\
\text { echimidinyl retronecine }^{c}\end{array}$ \\
\hline 7 & 10.3 & $270-335$ & $\begin{array}{l}{\left[\mathrm{M}+\mathrm{H}^{+}-595\right.} \\
\mathrm{MS} / \mathrm{MS}-577(100), \\
559(30), 529(40), 511 \\
(50), 499 \quad(30), 475 \\
(30), 457(80)\end{array}$ & 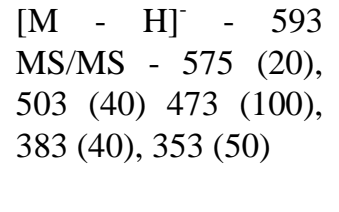 & vicenin- $2^{\mathrm{a}}$ \\
\hline 8 & 11.2 & 280 & $\begin{array}{l}{[\mathrm{M}+\mathrm{Na}]+-445} \\
\mathrm{MS} / \mathrm{MS}-427(100) \\
{[\mathrm{M}+\mathrm{H}]+-423} \\
\mathrm{MS} / \mathrm{MS}-405 \quad(100), \\
387(30), 357(80), 327 \\
(50)\end{array}$ & $\begin{array}{l}[\mathrm{M}-\mathrm{H}]]^{-}-421 \\
\text { MS/MS - } 403(20), \\
331(80), 301(100)\end{array}$ & catechin-C-arabinoside $^{\mathrm{a}}$ \\
\hline 9 & 12.6 & 280 & $\begin{array}{l}{[\mathrm{M}+\mathrm{H}]+-437} \\
\mathrm{MS} / \mathrm{MS}-419(100), \\
371(60), 341(40)\end{array}$ & & Catechin-C-rhamnoside $^{a}$ \\
\hline 10 & 13.0 & $270-335$ & $\begin{array}{l}{[\mathrm{M}+\mathrm{H}]+565} \\
\mathrm{MS} / \mathrm{MS}-547(100), \\
529(70), 511(80), 427 \\
(85)\end{array}$ & $\begin{array}{l}{[\mathrm{M}-\mathrm{H}]-563} \\
\text { MS/MS - } 545(40), \\
503(50), 473(80), \\
443(100), 383(60), \\
353(60)\end{array}$ & schaftoside $^{a}$ \\
\hline 11 & 14.0 & - & $\begin{array}{l}{[\mathrm{M}+\mathrm{H}]+-333} \\
\mathrm{MS} / \mathrm{MS}-315(20), 206 \\
(80), 179(100)\end{array}$ & & 2-galloyl glucose ${ }^{c}$ \\
\hline 12 & 15.1 & - & $\begin{array}{l}{[\mathrm{M}+\mathrm{Na}]+-587} \\
\mathrm{MS} / \mathrm{MS}-569(100), \\
551(40) \\
{[\mathrm{M}+\mathrm{H}]+-565} \\
\mathrm{MS} / \mathrm{MS}-547(100),\end{array}$ & {$[\mathrm{M}-\mathrm{H}]-563$} & isoschaftoside $^{\mathrm{a}}$ \\
\hline
\end{tabular}




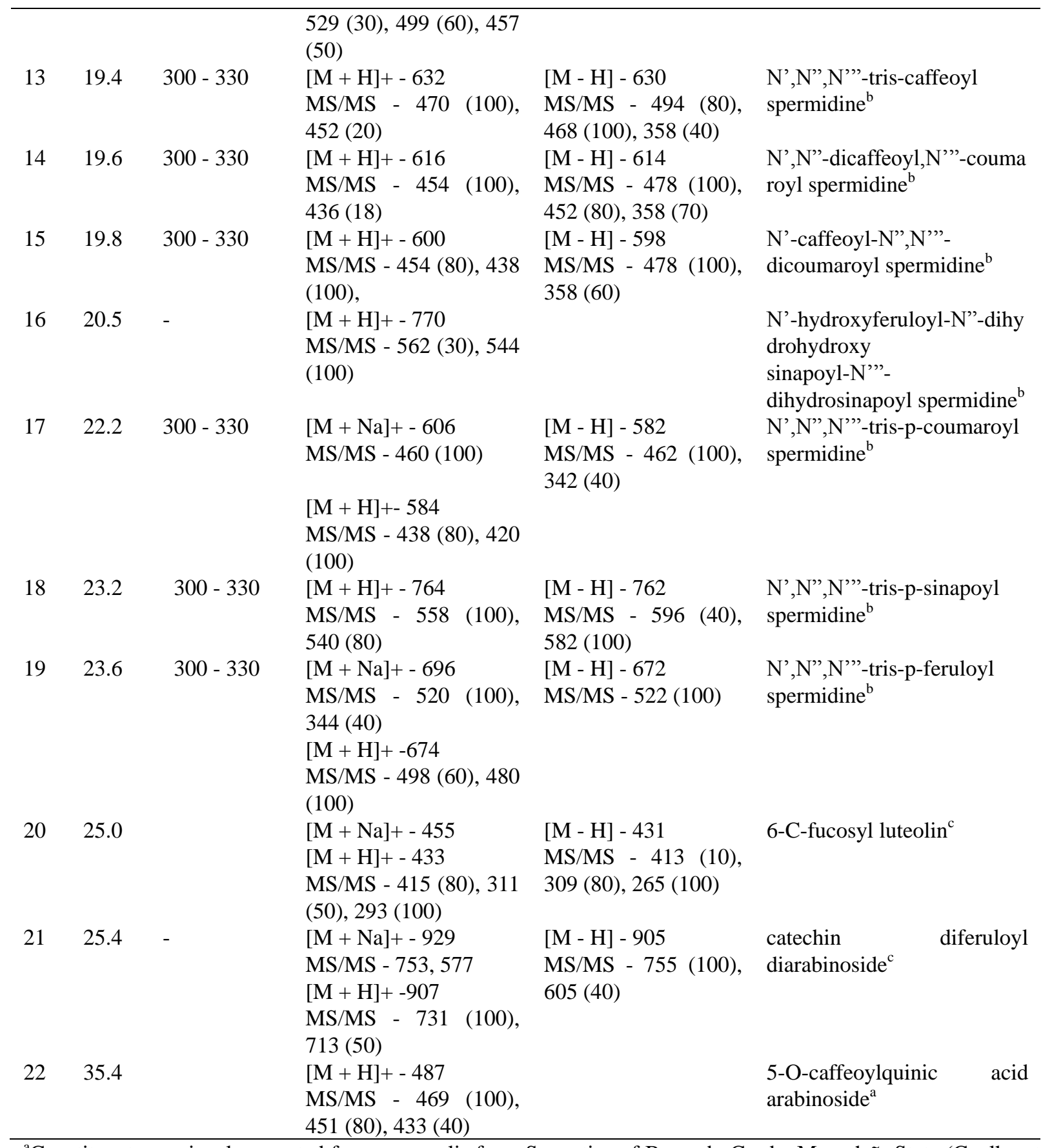

${ }^{a}$ Constituents previously reported for geopropolis from S. postica of Barra do Corda, Maranhão State (Coelho et al. 2015). ${ }^{b}$ Constituents identified based on MS spectral data reported by Negri et al. $(2011,2018)$, and Mihajlovic et al., (2015). ${ }^{\mathrm{c}}$ Constituents tentatively identified based on MS data.

\section{Discussion}

The potent antiviral activity of the extract of geopropolis from $S$. postica provided by beekeeper, against herpes simplex virus was reported previously (Coelho et al., 2015; Silva-Carvalho et al., 2015). The present study evaluated the effect of an experimentally prepared extract of geopropolis from S. postica (HMEG) on RV infected SIRC cells. Rubella was described in 1866, by Henry Veale, a British Army surgeon (Muscat et al., 2014). Generally, cells cultivated with RV strains cause cytopathic effects or morphological changes in the host cell (Carvalho et al. 2017). In this study, SIRC cells cultivated with RA 27/3 exhibited clear growth of the RV and readily detectable cytopathic effects. The replication of RV was observed on untreated SIRC cells cultivated with RA 27/3 after $48 \mathrm{~h}$, as described by Figueiredo et al., (2000). The growth of the RV, with the arrangement of 
organelles was not observed in cells infected and treated with HMEG. The binding-penetration assays indicated that HMEG inhibited RV entry into SIRC cells by interfering with the binding/ adsorption of the virions to the cellular receptor, and consequently caused not only a reduction of viral load but also a decrease of cytopathic effects and viral protein synthesis. Thus, vicenin-2 and schaftoside was been able to block the binding of RV with receptors on SIRC plasma membrane and prevent the penetration within cells, affecting the steps of viral cycle replication into SIRC cells or lead to the DNA degradation, before the virus entry into cells.

Endoplasmic reticulum, membranous networks of the cell, is a crucial organelle used for viral entry and viral replication. Rubella virus possesses the ability to rearrange cellular membranes to facilitate its viral replication (Lee \& Bowden, 2000, Petrova et al., 2016). The endoplasmic reticulum, Golgi complex, and mitochondria are often closely arranged around the virus replication complex, in RV infected SIRC cells (Lee \& Bowden, 2000). The results measured by qPCR and visualized by transmission electron microscopy (TEM) demonstrated a reduction in infectivity on the RV infected SIRC cells treated with HMEG. In TEM assay, was not observed the rearrangement of organelles, the typical replication complex, rubella virions and RV-like particles on infected SIRC cells treated with HMEG in concentrations of $0.6-68 \mathrm{ug} / \mathrm{mL}$. In qPCR assays was observed that the inhibition of the cytopathic effect and viral replication on infected and treated SIRC cells, was dose dependent. Thus, was observed that pre treatment of SIRC cells with HMEG, carried out $3 \mathrm{~h}$ before of the virus infection and post treatment $1 \mathrm{~h}$ after of virus infection, inhibited the viral replication. The post treatment exhibited the best antiviral activity. The results indicated that HMEG inhibited RV entry into target cells interfering with the binding/adsorption of the virions to the cellular receptor.

The pharmacological activities of propolis had been attributed to flavonoids, generally, its main constituents. The antiviral property of flavonoids is known, since 1940 (Kaul, Middleton, \& Ogra, 1985). Many flavonoids are used extensively in the fields of nutrition, food safety and health (Ahmad etal., 2015; Panche, Diwan \& Chandra, 2016; Kumar \& Pandey, 2013). Quercetin, naringin, hesperetin and catechin affected the replication and infectivity of some RNA and DNA viruses (Panche, Diwan \& Chandra, 2016; Kumar \& Pandey, 2013). The antioxidant activity of flavonoids can to inhibit essential enzymes associated with the life cycle of viruses (Kumar \& Pandey, 2013), disrupt cell membranes, to prevent viral binding and penetration into cells and increase the host cell self-defense mechanism (Friedman, 2014). Moreover, can inhibit the enzyme viral polymerase and the bind of viral nucleic acid or viral capsid proteins on host cell receptor (Hossain et al., 2014; Kumar \& Pandey, 2013; Song et al., 2015). Several flavone 6-C-monoglycosides exhibited potent, in vitro, antiviral effect (Wang et al., 2012). The flavonoids baicalein, fisetin, and quercetagetin exhibited high antiviral activity against Chikungunya virus and extracellular Chikungunya vírus particles (Lani et al., 2016) and demonstrated anti-noroviral activity against murine norovirus and feline calicivirus (Seo et al., 2016).

Vicenin-2 and schaftoside are apigenin derivatives. The antiviral activity of apigenin derivatives and other flavones are known, since 1994 (Panche, Diwan \& Chandra, 2016). Apigenin exhibited antiviral activity against eleven different types of viruses (Ahmad et al., 2015), among them, herpes simplex virus, aujeszky virus (Kumar \& Pandey, 2013), poliovirus type 2 (Visintini Jaime et al., 2013), enterovirus 71 (Ji et al., 2015; Lv et al., 2014; Wang et al., 2014) and hepatitis C virus (Shibata et al., 2014). Beside this, apigenin and luteolin inhibited the neuraminidase of influenza virus (Liu et al., 2008) and exhibited high antiviral activity against oseltamivir- and peramivir-sensitive and oseltamivir- and peramivir-resistant influenza viruses (Kai et al., 2014). 3,2'-Dihydroxyflavone and 3,4'dihydroxyflavone, exhibited potent anti-influenza activity, attributed to the inhibition of the viral neuraminidase activity and viral penetration into cells (Hossain et al., 2014). Luteolin 7-O-methylether-3'-O-beta-D-glucoside exerted an inhibitory effect on the first stage of herpes virus-2 infection, attributed to the inhibition of herpes virus-2 binding to receptor of the cell membrane and its penetration into the cell (Behbahani, Zadeh, \& Mohabatkar, 2013). An extract of Mexican propolis, possessing high contents of quercetin, pinocembrin and naringenin exhibited antiviral activity against Canine Distemper virus (González-Búrquez et al., 2018). Low contents of flavonoids inhibited the replication of Hand Foot Mouth Disease, caused from human enterovirus A71 infection, which can produce severe neurological complications, mainly in young children (Min et al., 2018). Oroxylin A (bacalein-6-methyl ether, an O-methylated flavone), exhibited antiviral activity against Coxsackievirus B3 (Kwon et al., 2016).

The antiviral activity of caffeolyquinic acids, catechins and hydroxycinnamic acid amide derivatives was also known. An aqueous extract of Brazilian green propolis, rich in caffeoylquinic acids derivatives, exhibited anti-influenza activity (Takemura et al., 2012; Urushisaki et al., 2011). Catechins inhibited RNA replication of influenza virus (Song, Lee, \& Seong, 2005), and the process of fusion of HIV virus with the cell receptor (Liu et al., 2005). Hydroxycinnamic acid amide derivatives or triacylated spermidines derivatives exhibited antimicrobial activity against viruses, bacteria and fungi (Mihajlovic et al., 2015). The geopropolis from $S$. 
Postica is used by the population of Maranhão State, in the treatment of wounds (Coelho et al., 2015; Souza et al., 2015). Pyrrolizidine alkaloids exhibited antimicrobial activity and are promising prototypes for new drugs, especially for topical use (Silva Negreiros Neto et al., 2016).

\section{Conclusion}

There is not an effective treatment for rubella virus infection. This study indicated that geopropolis from Scaptotrigona postica of Barra do Corda, Maranhão State, possess potent antiviral activity against Rubella, a Togaviridae virus. HMEG at low concentrations, was able to inhibit the replication of Rubella virus. The best antiviral activity was observed in the post treatment with HMEG. Results of cell viability and cell proliferation assays indicated that HMEG was not toxic to cultured SIRC cells. The results obtained by viral binding assay, antiviral assay, PCR, real-time PCR, and transmission electron microscopy demonstrate that HMEG can be able to inhibit the production of infectious RV particles. This activity could be attributed to the high content of vicenin- 2 and schaftoside, which probably acted blocking the RV binding to the receptor of SIRC cell membrane, and the penetration within the cell, preventing the viral replication.

\section{Acknowledgements}

All authors are very grateful to the excellent researcher and friend, one co-author of this work, Prof. Dr. Cristina Adelaide Figueiredo, in memorium.

This study was kindly supported by CAPES and FAPESP (Fundação de Apoio à Pesquisa do Estado de São Paulo). Wilson Melo gently provided a geopropolis sample.

\section{Conflict of interests}

We confirm that there are not conflict of interest associated with this work.

List of Abbreviations

CRS - congenital rubella syndrome, EPEG - experimentally prepared hydroethanolic extract from geopropolis, DEM - Direct electron microscopy, DMEM - Dulbecco's minimum Eagle essential medium, PBS - phosphate buffered saline, FBS - fetal bovine serum, mRNA - Messeger ribonucleic acid, MTT 3-(4,5-Dimethylthiazol-2-yl)-2,5-diphenyltetrazolium bromide, PCR - Polimerase chain reaction, qPCR quantitative polimerase chain reaction, RV - Rubella Virus, SIRC - Serum institut Rabbit Cornea (SIRC) cells, TEM - Transmission electron microscopy, WHO - World Health Organization

\section{References}

Abernathy, E., Cabezas, C., Sun, H., Zheng, Q., Chen, M., Castillo-Solorzano, C., ... Icenogle, J. (2009). Confirmation of rubella within 4 days of rash onset: comparison of rubella virus RNA detection in oral fluid with immunoglobulin M detection in serum or oral fluid. Journal of Clinical Microbiology, 47, 182-188. https://doi.org/10.1128/JCM.01231-08

Ahmad, A., Kaleem, M., Ahmed, Z., \& Shafiq, H. (2015). Therapeutic potential of flavonoids and their mechanism of action against microbial and viral infections-A review. Food Research International, 77, 221-235. https://doi.org/10.1016/j.foodres.2015.06.021

Bankova, V., Galabov, A. S., Antonova, D., Vilhelmova, N., \& Di Perri, B. (2014). Chemical composition of Propolis Extract $\mathrm{ACF}{ }^{\circledR}$ and activity against herpes simplex virus. Phytomedicine, 21, 1432-1438. https://doi.org/10.1016/j.phymed.2014.04.026.

Batista, M. C. A., Abreu, B. V. B., Dutra, R. P., Cunha, M. S., Mendonça do Amaral, F. M., Torres, L. M. B., Ribeiro, M. N. S. (2016). Chemical composition and antioxidant activity of geopropolis produced by Melipona fasciculata (Meliponinae) in flooded fields and cerrado areas of Maranhão State, northeastern Brazil. Acta Amazonica, 46, 315-322. http://dx.doi.org/10.1590/1809-4392201600034

Behbahani, M., Zadeh, M. S., \& Mohabatkar, H. (2013). Evaluation of antiherpetic activity of crude extract and fractions of Avicenna marina, in vitro. Antiviral Research, 97, 376-80. https://doi.org/10.1016/j.antiviral.2013.01.001.

Berretta, A. A., Arruda, C., Miguel, F. G., Baptista, N., Nascimento, A. P., Marquele Oliveira, F., ... Bastos, J. K. (2017). Functional Properties of Brazilian Propolis: From Chemical Composition Until the Market. Agricultural and Biological Sciences » "Superfood and Functional Food - An Overview of Their Processing and Utilization", book edited by Viduranga Waisundara and Naofumi Shiomi, ISBN 978-953-51-2920-2.

Búfalo, M. C., Figueiredo, A. S., De Sousa, J. P. B., Candeias, J. M. G., Bastos, J. K., \& Sforcin J. M. (2009). Anti-poliovirus activity of Baccharis dracunculifolia and propolis by cell viability determination and 
real-time PCR. Journal of Applied Microbiology, 107, 1669-1680.

https://doi.org/10.1111/j.1365-2672.2009.04354.x

Carneiro, M. J., López, B. G-C., Lancellotti, M., Franchi G. C., Nowill, A. E., \& Sawaya, A. C. H. F. (2016). Evaluation of the chemical composition and biological activity of extracts of Tetragonisca angustula propolis and Schinus terebinthifolius Raddi (Anacardiaceae). Journal of Apicultural Research, 55, 315-323. https://doi.org/10.1080/00218839.2016.1243295

Carvalho, N. D., Mendonça, R. Z., Oliveira, M. I., Curti, S. P., Barbosa, T. F., Silva, P. E., ... Figueiredo, C. A. (2017). Antiviral activity of hemolymph of Podalia against rubella virus. Cytotechnology, 69, 31-37. https://doi.org/10.1007/s10616-016-0035-6

Coelho, G. R., Mendonça, R. Z., De Senna, V. K., Figueiredo, C. A., Badari, J. C., Taniwaki, N., ... Negri, G. (2015). Antiviral action of hydromethanolic extract of geopropolis from scaptotrigona postica against antiherpes simplex virus (HSV-1). Evidence-Based Complementary and Alternative Medicine. http://dx.doi.org/10.1155/2015/296086

Curti, S. P., Figueiredo, C. A., de Oliveira, M. I., Andrade, J. Q., Zugaib, M., Frugis Yu, A. L., Oliveira, D.B., \& Durigon, E. L. (2013). Molecular epidemiology of rubella viruses involved in congenital rubella infections in São Paulo, Brazil, between 1996 and 2009. Journal of Medical Virology, 85, 2034-2041. https://doi.org/10.1002/jmv.23675.

Dübecke, A., Beckh, G., \& Lüllmann, C. (2011). Pyrrolizidine alkaloids in honey and bee pollen. Food additives \& contaminants. Part A, Chemistry, analysis, control, exposure \& risk assessment, 28, 348-58. https://doi.org/10.1080/19440049.2010.541594.

Dutra, R. P., De Barros, A. B. V., Cunha, M. S., Batista, M. C. A., Torres, L. M., Nascimento, F. R., Ribeiro, M. N., \& Guerra, R. N. (2014). Phenolic acids, hydrolyzable tannins, and antioxidant activity of geopropolis from the stingless bee melipona fasciculata smith. Journal of Agricultural and Food Chemistry, 62, 2549-2557. https://doi.org/10.1021/jf404875v.

Elliger, C. A., Chan, B. G., Waiss, A. C., Lundin, R. E., \& Haddon, W. F. (1980). C-Glycosylflavones from Zea mays that inhibit insect development. Phytochemistry, 293-297. https://doi.org/10.1016/S0031-9422(00)81977-9.

Ferreira, J. M., Fernandes-Silva, C. C., Salatino, A., Message, D., \& Negri, G. (2017). Antioxidant Activity of a Geopropolis from Northeast Brazil: Chemical Characterization and Likely Botanical Origin. Evidence-Based Complementary and Alternative Medicine. https://doi.org/10.1155/2017/4024721

Figueiredo, C. A., Oliveira, M. I., Curti, S. P., Cruz, A. S., Moreira, E., Afonso A. M. S., \& Salles-Gomes, L. F. (2000). RC-IAL cell line: sensitivity of rubella virus grow. Revista de Saúde Pública, 34, 353-357.

Friedman, M. (2014). Antibacterial, antiviral, and antifungal properties of wines and winery byproducts in relation to their flavonoid content. Journal of Agricultural and Food Chemistry, 62, 6025-6042. https://doi.org/10.1021/j5501266s.

González-Búrquez, M. J., González-Díaz, F. R., García-Tovar, C. G., Carrillo-Miranda, L., Soto-Zárate, C. I., Canales-Martínez, M. M., ... Fonseca-Coronado, S. (2018). Comparison between In Vitro Antiviral Effect of Mexican Propolis and Three Commercial Flavonoids against Canine Distemper Virus. Evidence-Based Complementary and Alternative Medicine. https://doi.org/10.1155/2018/7092416

Gualberto, F. A. S., Curti, S. P., de Oliveira, M. I., Moraes-Vasconcelos, D., \& Figueiredo, C. A., (2013). Intermittent rash, lymph node swelling, arthralgia and vaccinal viral detection after rubella immunization. Journal of Clinical Virology, 56, 93-95. https://doi.org/10.1016/j.jcv.2012.07.017.

Hossain, M. K., Choi, H. Y., Hwang, J.-S., Dayem, A. A., Kim, J.-H., Kim, Y. B., Poo, H., \& Cho, S. G. (2014). Antiviral activity of 3,4'-dihydroxyflavone on influenza a virus. Journal of Microbiology, 52, 521-526. https://doi.org/10.1007/s12275-014-4212-z.

Huang, S., Zhang, C.-P., Wang, K., Li, G., \& Hu, F. L. (2014). Recent advances in the chemical composition of propolis. Molecules, 19, 19610-19632. https://doi.org/10.3390/molecules191219610.

Ji, P., Chen, C., Hu, Y., Zhan, Z., Pan, W., Li, R., Li, E., Ge, H. M., \& Yang, G. (2015). Antiviral activity of Paulownia tomentosa against Enterovirus 71 of hand, foot, and mouth disease. Biological Pharmaceutical Bulletin, 38, 1-6. https://doi.org/10.1248/bpb.b14-00357.

Kai, H., Obuchi, M., Yoshida, H., Watanabe, W., Tsutsumi, S., Park, Y. K., Matsuno, K., Yasukawa, K., \& 
Kurokawa, M. (2014). In vitro and in vivo anti-influenza virus activities of flavonoids and related compounds as components of Brazilian propolis (AF-08). Journal of Functional Foods, 8, 214-223. https://doi.org/10.1016/j.jff.2014.03.019

Karar, M. G. E., \& Kuhnert, N. (2015). UPLC-ESI-Q-TOF-MS/MS Characterization of Phenolics from Crataegus monogyna and Crataegus laevigata (Hawthorn) Leaves, Fruits and their Herbal Derived Drops (Crataegutt Tropfen). Journal of Chemical Biology \& Therapeutics, 1, 102. https://doi.org/10.4172/2572-0406.1000102

Kaul, T., Middleton, E., \& Ogra, P. (1985) Antiviral effect of flavonoids on human viruses. Journal Medicinal Virology, 15, 71-79. https://doi.org/10.1002/jmv.1890150110

Kwon, B-E., Song, J-H., Song, H-H., Kang, J. W., Hwang, S. N., Rhee, K-J., ... Ko, H-J. (2016). Antiviral Activity of Oroxylin A against Coxsackievirus B3 Alleviates Virus-Induced Acute Pancreatic Damage in Mice. PLoS ONE 11, e0155784. https://doi.org/10.1371/journal.pone.0155784

Kumar, S., \& Pandey, A. K. (2013). Chemistry and biological activities of flavonoids: An overview. The Scientific World Journal. Hindawi Publishing Corporation. http://doi.org/10.1155/2013/162750

Lani, R., Hassandarvish, P., Shu, M. H., Phoon, W. H., Chu, J. J. H., Higgs, S., Vanlandingham, D., Bakar, S. A., \& Zandi, K. (2016). Antiviral activity of selected flavonoids against Chikungunya virus. Antiviral Research, 133, 50-61. https://doi.org/10.1016/j.antiviral.2016.07.009

Lee, J. Y., \& Bowden, D. S. (2000). Rubella virus replication and links to teratogenicity. Clinical Microbiology Reviews, 13, 571-587.

Li, A., Xuan, H., Sun, A., Liu, R., \& Cui, J. (2016). Preparative separation of polyphenols from water-soluble fraction of Chinese propolis using macroporous absorptive resin coupled with preparative high performance liquid chromatography. Journal of Chromatography B Analytical Technological Biomedical Life Science, 1012, 42-49. https://doi.org/10.1016/j.jchromb.2015.12.038. Epub 2016 Jan 11.

Liu, A. L., Liu, B., Qin, H. L., Lee, S. M., Wang, Y. T., \& Du, G. H. (2008). Anti-influenza virus activities of flavonoids from the medicinal plant Elsholtzia rugulosa. Planta Medica, 74, 847-851. https://doi.org/10.1055/s-2008-1074558

Liu, S., Lu, H., Zhao, Q., He, Y., Niu, J., Debnath, A. K., Wu, S., \& Jiang, S. (2005). Theaflavin derivatives in black tea and catechin derivatives in green tea inhibit HIV-1 entry by targeting gp41. Biochimica et Biophysica Acta, 1723, 270-281. https://doi.org/10.1016/j.bbagen.2005.02.012

Lv, X., Qiu, M., Chen, D., Zheng, N., Jin, Y., \& Wu, Z. (2014). Apigenin inhibits enterovirus 71 replication through suppressing viral IRES activity and modulating cellular JNK pathway. Antiviral Research, 109, 30-41. https://doi.org/10.1016/j.antiviral.2014.06.004.

Martínez-Torres, A. O., Mosquera, M. M., De Ory, F., González-Praetorius, A., \& Echevarría, J. E. (2016). Genetic Characterization of Rubella Virus Strains Detected in Spain, 1998-2014. PLoS One, 13, e0162403. https://doi.org/10.1371/journal.pone.0162403

Massaro, C. F., Katouli, M., Grkovic, T., Vu, H., Quinn, R. J., Heard, T. A., ... Brooks, P. (2014). Anti-staphylococcal activity of C-methyl flavanones from propolis of Australian stingless bees (Tetragonula carbonaria) and fruit resins of Corymbia torelliana (Myrtaceae). Fitoterapia, 95, 247-257. https://doi.org/10.1016/j.fitote.2014.03.024.

Mihajlovic, L., Radosavljevic, J., Burazer, L., Smiljanic, K., \& Cirkovic, V. T. (2015). Composition of polyphenol and polyamide compounds in common ragweed (Ambrosia artemisiifolia L.) pollen and sub-pollen particles. Phytochemistry, 109, 125-132. https://doi.org/10.1016/j.phytochem.2014.10.022.

Min, N., Leong, P. T., Lee, R. C. H., Khuan, J. S. E., \& Chu, J. J. H. (2018). A flavonoid compound library screen revealed potent antiviral activity of plant-derived flavonoids on human enterovirus A71 replication. Antiviral Research, 150, 60-68. https://doi.org/10.1016/j.antiviral.2017.12.003.

Montenegro, G., \& Mejías, E. (2013). Biological applications of honeys produced by Apis mellifera. Biological Research, 46, 341-345. https://doi.org/10.4067/S0716-97602013000400005.

Moreira, R., Pereira, D. M., Valentão, P., \& Andrade, P. B. (2018). Pyrrolizidine Alkaloids: Chemistry, Pharmacology, Toxicology and Food Safety. International Journal Molecular Science, 19, 1668. https://doi.org/10.3390/ijms19061668.

Muscat, M., Shefer, A., Ben Mamou, M., Spataru, R., Jankovic, D., Deshevoy, S., Butler, R., \& Pfeifer, D. 
(2014). The state of measles and rubella in the WHO European Region, 2013. Clinical Microbiology and Infection, 20, 12-18. https://doi.org/10.1111/1469-0691.12584.

Negri, G., Teixeira, E. W., Alves, M. L., Moreti, A. C., Otsuk, I. P., Borguini, R. G., \& Salatino, A. (2011). Hydroxycinnamic acid amide derivatives, phenolic compounds and antioxidant activities of extracts of pollen samples from Southeast Brazil. Journal of Agricultural and Food Chemistry, 59, 5516-5522. https://doi.org/10.1021/jf200602k.

Negri, G., Carelli Barreto, L. M. R., Sper, F. L., de Carvalho, C., \& Campos, M. G. R. (2018). Phytochemical analysis and botanical origin of Apis mellifera bee pollen from the municipality of Canavieiras, Bahia State, Brazil. Brazilian Journal Food Technology, 21, e2016176. http://dx.doi.org/10.1590/1981-6723.17616

Nina, N., Quispe, C., Jiménez-Aspee, F., Theoduloz, C., Feresín, G. E., Lima, B., Leiva, E., \& Schmeda-Hirschmann, G. (2015). Antibacterial Activity, Antioxidant Effect and Chemical Composition of Propolis from the Región del Maule, Central Chile. Molecules, 20, 18144-67. https://doi.org/10.3390/molecules201018144.

Nolkemper, S., Reichling, J., Sensch, K. H., \& Schnitzler, P. (2010). Mechanism of herpes simplex virus type 2 suppression by propolis extracts. Phytomedicine, 17, 132-138. https://doi.org/10.1016/j.phymed.2009.07.006.

Oldoni, T. L. C., Oliveira, S. C., Andolfatto, S., Karling, M., Calegari, M. A., Sado, R. Y., ... Lima, V. A. (2015). Chemical Characterization and Optimization of the Extraction Process of Bioactive Compounds from Propolis Produced by Selected Bees Apis mellifera. Journal of the Brazilian Chemical Society, 26, 2054-2062. http://dx.doi.org/10.5935/0103-5053.20150186

Osés, S. M., Pascual-Maté, A., Fernández-Muiño, M. A., López-Díaz, T. M., \& Sancho, M. T. (2015). Bioactive properties of honey with propolis. Food Chemistry, 196, 1215-1223. https://doi.org/10.1016/j.foodchem.2015.10.050.

Panche, A. N., Diwan, A. D., \& Chandra, S. R. (2016). Flavonoids: an overview. Journal of Nutritional Science, 5, e47, 1-15. https://doi.org/10.1017/jns.2016.41

Parkman, P. D. (1996). Togaviruses: Rubella Virus. In: Baron S, editor. Medical Microbiology. 4th edition. Galveston (TX): University of Texas Medical Branch at Galveston; Chapter 55.

Petrova, E. K., Dmitrieva, A. A., Trifonova, E. A., Nikitin, N. A., \& Karpova, O. V. (2016). The key role of rubella virus glycoproteins in the formation of immune response, and perspectives on their use in the development of new recombinant vaccines. Vaccine, 34, 1006-1111.

https://doi.org/10.1016/j.vaccine.2016.01.010.

Pippi, B., Lana, A. J., Moraes, R. C., Güez, C. M., Machado, M., de Oliveira, L. F. S., Lino von Poser, G., \& Fuentefria, A. M. (2015). In vitro evaluation of the acquisition of resistance, antifungal activity and synergism of Brazilian red propolis with antifungal drugs on Candida spp. Journal of Applied Microbiology, 118, 839-850. https://doi.org/10.1111/jam.12746.

Plotkin, S. A. (2011). History of Rubella Vaccines and the Recent History of Cell Culture. In History of Vaccine Development (pp. 219-231). New York, NY: Springer New York.

Rasbach, A., Abel, T., Münch, R. C., Boller, K., Schneider-Schaulies, J., \& Buchholz, C. J. 2013. The Receptor Attachment Function of Measles Virus Hemagglutinin Can Be Replaced with an Autonomous Protein That Binds Her2/neu While Maintaining Its Fusion-Helper Function. Journal of Virology, 87, 6246-6256. https://doi.org/10.1128/JVI.03298-12.

Saeed, F., Ahmad, R. S., Arshad, M. U., Niaz, B., Batool, R., Naz, R., \& Rasul, S. H. A. (2016) Propolis to Curb Lifestyle Related Disorders: An Overview. International Journal of Food Properties, 19, 420-437. https://doi.org/10.1080/10942912.2012.745131

Salas, A. L., Alberto, M. R., Zampini, I. C., Cuello, A. S., Maldonado, L., Ríos, J. L., Schmeda-Hirschmann, G., \& Isla, M. I. (2016). Biological activities of polyphenols-enriched propolis from Argentina arid regions. Phytomedicine, 23, 27-31. https://doi.org/10.1016/j.phymed.2015.11.007.

Santos, H. F. D., Campos, J. F., Santos, C. M. D., Balestieri, J. B. P., Silva, D. B., Carollo, C. A., .. Dos, S. E. L. (2017). Chemical Profile and Antioxidant, Anti-Inflammatory, Antimutagenic and Antimicrobial Activities of Geopropolis from the Stingless Bee Melipona orbignyi. International Journal Molecular Science, 18, 953. https://doi.org/10.3390/ijms18050953. 
Sartori, G., Pesarico, A. P., Pinton, S., Dobrachinski, F., Roman, S. S., Pauletto, F., Rodrigues, L. C. Jr., \& Prigol, M. (2012). Protective effect of brown Brazilian propolis against acute vaginal lesions caused by herpes simplex virus type 2 in mice: involvement of antioxidant and anti-inflammatory mechanisms. Cell Biochemistry and Function, 30, 1-10. https://doi.org/10.1002/cbf.1810.

Sawaya, A. C. H. F., Calado, J. C. P., Santos, L. C., Marcucci, M. C., Akatsu, I. P., Soares, A. E. E., ... Eberlin, M. N. (2009). Composition and antioxidant activity of propolis from three species of Scaptotrigona stingless bees. Journal of ApiProduct and ApiMedical Science, 1, 37-42.

https://doi.org/10.3896/IBRA.4.01.2.03

Schnitzler, P., Neuner, A., Nolkemper, S., Zundel, C., Nowack, H., Sensch, K. H., \& Reichling, J. (2010). Antiviral Activity and Mode of Action of Propolis Extracts and Selected Compounds. Phytotherapy Research, 24(S1), S20-S28. https://doi.org/10.1002/ptr.2868.

Seo, D. J., Jeon, S. B., Oh, H., Lee, B. H., Lee, S. Y., Oh, S. H., Jung, J. Y., \& Choi, C. (2016). Comparison of the antiviral activity of flavonoids against murine norovirus and feline calicivirus. Food Control, 60, 25-30. http://doi.org/10.1016/j.foodcont.2015.07.023

Shibata, C., Ohno, M., Otsuka, M., Kishikawa, T., Goto, K., Muroyama, R., Kato, N., Yoshikawa, T., Takata, A., \& Koike, K. (2014). The flavonoid apigenin inhibits hepatitis $C$ virus replication by decreasing mature microRNA122 levels. Virology, 462-463, 42-48. http://doi.org/10.1016/j.virol.2014.05.024

Shimizu, T., Hino, A., Tsutsumi, A., Park, Y. K., Watanabe, W., \& Kurokawa, M. (2008). Anti-influenza virus activity of propolis in vitro and its efficacy against influenza infection in mice. Antiviral Chemistry \& Chemotherapy, 19, 7-13. http://doi.org/10.1177/095632020801900102

Silva-Carvalho, R., Baltazar, F., Almeida-Aguiar, C., \& Almeida-Aguiar, C. (2015). Propolis: A Complex Natural Product with a Plethora of Biological Activities That Can Be Explored for Drug Development. Evidence-Based Complementary and Alternative Medicine. https://doi.org/10.1155/2015/206439

Silva, N. N. T., Gardner, D., Hallwass, F., Leite, A. J. M., de Almeida, C. G., Silva, L. N., ... Giordani, R. B. (2016). Activity of pyrrolizidine alkaloids against biofilm formation and Trichomonas vaginalis. Biomedical Pharmacotherapy, 83, 323-329. https://doi.org/10.1016/j.biopha.2016.06.033.

Song, J.-H., Kwon, B.-E., Jang, H., Kang, H., Cho, S., Park, K., Hyun-Jeong Ko, H-J., \& Kim, H. (2015). Antiviral Activity of Chrysin Derivatives against Coxsackievirus B3 in vitro and in vivo. Biomolecules \& Therapeutics, 23, 465. http://doi.org/10.4062/biomolther.2015.095

Song, J. M., Lee, K. H., \& Seong, B. L. (2005). Antiviral effect of catechins in green tea on influenza virus. Antiviral Research, 68, 66-74. http://doi.org/10.1016/j.antiviral.2005.06.010

Souza, H. R., Corrêa, A. M. S., Cruz-Barros, M. A. V., \& Albuquerque, P. M. C. (2015). Espectro polínico da própolis de Scaptotrigona aff. postica (Hymenoptera, Apidae, Meliponini) em Barra do Corda, MA, Brasil. Acta Amazonica, 45, 307-316. http://doi.org/10.1590/1809-4392201403663

Silva, T. M. S., Souza S. A., Dias, T. L. M. F., Silva, T. M. G., Falcão, R. A., Alexandre, M. M. S., Silva, E. M. S., \& Camara, C. A. (2014). Chemical composition, antinociceptive and free radical-scavenging activities of geopropolis from Melipona subnitida Ducke (Hymenoptera: Apidae: Meliponini). Sociobiology, 61, 560-565. http://doi.org/10.13102/sociobiology.v61i4.560-565

Takemura, T., Urushisaki, T., Fukuoka, M., Muto, J-H., Hata, T., Okuda, Y., Hori, S., Tazawa, S., Araki, Y., \& Kuwata, K. (2012). 3,4-Dicaffeoylquinic Acid, a Major Constituent of Brazilian Propolis, Increases TRAIL Expression and Extends the Lifetimes of Mice Infected with the Influenza A Virus. Evidence-Based Complementary and Alternative Medicine : ECAM. http://doi.org/10.1155/2012/946867

Urushisaki, T., Takemura, T., Tazawa, S., Fukuoka, M., Hosokawa-Muto, J., Araki, Y., \& Kuwata, K. (2011). Caffeoylquinic acids are major constituents with potent anti-influenza effects in brazilian green propolis water extract. Evidence-Based Complementary and Alternative Medicine. http://doi.org/10.1155/2011/254914

Valenzuela-Barra, G., Castro, C., Figueroa, C., Barriga, A., Silva, X., de Las Heras, B., Hortelano, S., \& Delporte, C. (2015). Anti-inflammatory activity and phenolic profile of propolis from two locations in Región Metropolitana de Santiago, Chile. Journal of Ethnopharmacology, 168, 37-44. http://doi.org/10.1016/j.jep.2015.03.050

Visintini Jaime, M. F., Redko, F., Muschietti, L. V, Campos, R. H., Martino, V. S., \& Cavallaro, L. V. (2013). In 
vitro antiviral activity of plant extracts from Asteraceae medicinal plants. Virology Journal, 10, 245. http://doi.org/10.1186/1743-422X-10-245

Wang, J., Zhang, T., Du, J., Cui, S., Yang, F., \& Jin, Q. (2014). Anti-enterovirus 71 effects of chrysin and its phosphate ester. PLOS ONE, 9, e89668. http://doi.org/10.1371/journal.pone.0089668

Wang, Y., Chen, M., Zhang, J., Zhang, X. L., Huang, X. J., Wu, X., Zhang, Q. W., Li, Y. L., \& Ye, W. C. (2012). Flavone $\mathrm{C}$-glycosides from the leaves of Lophatherum gracile and their in vitro antiviral activity. Planta Medica, 78, 46-51. http://doi.org/10.1055/s-0031-1280128

World Health Organization. (2017). WHO. Retrieved from http://www.who.int/en/

Yildirim, A., Duran, G. G., Duran, N., Jenedi, K., Bolgul, B. S., Miraloglu, M., \& Muz, M. (2016). Antiviral Activity of Hatay Propolis Against Replication of Herpes Simplex Virus Type 1 and Type 2. Medical Science Monitor, 22, 422-430. http://doi.org/10.12659/MSM.897282

\section{Copyrights}

Copyright for this article is retained by the author(s), with first publication rights granted to the journal.

This is an open-access article distributed under the terms and conditions of the Creative Commons Attribution license (http://creativecommons.org/licenses/by/4.0/). 